\title{
PENGGUNAAN YOUTUBE SEBAGAI MEDIA PEMBELAJARAN BAHASA INGGRIS PADA MASA PANDEMI COVID 19
}

\author{
RASMAN \\ MTsN Luwu Utara ,KabupatenLuwu Utara \\ e-mail : rasmanspd1971@gmail.com
}

\begin{abstract}
ABSTRAK
Era Pandemi covid 19 telah menghambat proses pembelajaran secara konvensional atau pembelajaran secara tatap muka di sekolah. Tentu saja diperlukan mencari solusi untuk menanggulangi hambatan tersebut. Melalui Pembelajaran secara Daring menjadi salah satu cara yang dapat digunakan oleh guru dan siswa untuk mengatasi masalah tersebut. Mata pelajaran Bahasa Inggris adalah satu diantara mata pelajaran yang ada pada jenjang SMP/MTs./sederajat. Namun Sebagian siswa menganggap pelajaran ini sulit dipahami terutama bagi siswa yang belum pernah mempelajari bahasa inggris pada sekolah jenjang sebelumnya. Tujuan diadakannya penelitian ini yaitu supaya bisa mengetahui manfaat yang dapat diambil dari youtube untuk media pembelajaran bahasa inggris secara daring di tengah pandemi covid 19. Penelitian ini yaitu penelitian yang bersifat kualitatif yang mana penulis menggunakan pengamatan (observasi), tanya jawab (wawancara) dan mempelajari dokumen penelitian sebelumnya. Hasil pada penelitian ini menunjukan bahwa dengan memanfaatkan media youtube mampu meningkatkan pemahaman siswa sehingga prestasi belajat sisiwa meningkat ketimbang menggunakan media lain seperti menggunakan e-book atau whatsapp tetapi hal in tidak lupuk dari kendala yakni kurang optimalnya pengawasan guru dan orang tua terhadap siswa, kurang bagusnya sinyal atau jaringan internet, dan mahalnya kuota bahkan masih adanya siswa yang belm memiliki $\mathrm{Hp}$ android adalah kendala yang ada dalam penggunaan youtube sebagai media pembelajaran. Tantangan dunia pendidikan dalam memenuhi kebutuhan generasi internet cukup besar. Hal ini disebabkan oleh pengalaman hidup mereka yang berbeda khusus nya pengalaman dalam menggunakan teknologi. Internet sendiri membuka banyak kemungkinan pengintegrasian teknologi dalam pembelajaran dikelas. Youtube adalah adalah salah satu media pembelajaran yang bisa diintegrasikan dalam pembelajaran mata pelajaran bahasa inggris yang dianggap sulit oleh siswa. Tujuan penelitian ini adalah untuk melihat sejauh mana Youtube dapat digunakan sebagai media pembelajaran dalam mata Bahasa Inggris. Hasil penelitian menunjukkan bahwa video yang ada di Youtube dapat digunakan sebaga salah satu media pembelajaran.
\end{abstract}

Kata kunci: media pembelajaran, youtube, bahasa inggris

\section{PENDAHULUAN}

Memasuki era revolusi industri 4.0. Salah satu dampak perubahan di era ini banyaknya satuan pendidikan yang telah menerapkan teknologi digital dalam proses pembelajaran. Teknologi digital menjadi media pembelejaran yang berperan penting untuk meningkatkan kemampuan dan keterampilan peserta didik. Di era teknologi informasi, Salah satu diantara adalah pembelajaran bahasa inggris karena bahasa inggris adalah bahasa yang bersifat universal atau mendunia dan merupakan bahasa yang cukup banyak dipelajari dan ditelaah masyarakat diberbagai negara di dunia.

Era covid 19 merupakan permasalahan atau hambatan dalam proses belajar secara daring tersebut. Baik berupa hambatan yang berasal dari luar diri siswa contohnya sarana prasarana, media yang digunakan ataupun model pembelajaran, dan masih banyak permasalahan lainnya. Selain permasalahan dari luar tadi, terdapat juga hambatan yang datang dari dalam diri siswa itu sendiri. Salah satu contohnya adalah motivasi atau semangat belajar siswa. Mengacu pada hasil pengamatan yang sudah dilaksanakan penulis pada saat kegiatan pembelajaran bahasa inggris (Tenses/grammar;reading text; Listening; Speaking dan Writing.). Salah satu permasalahan itu adalah kurangnya semangat belajar siswa dengan 
metode ceramah yang bersifat monotom dan mebosankan . Hal ini dapat dilihat dari respon siswa pada waktu proses pembelajaran dilakukan di grup whatsApp (WA) pelajaran bahasa inggris. dipadukan sebagai alat untuk melengkapi aktivitas pembelajaran bahasa (Martins, 2015). Salah satu media teknologi yang sering digunakan saat ini adalah aplikasi di telepon genggam. Hasil penelitian menunjukan bahwa siswa yang banyak berinteraksi dengan aplikasi di telepon genggam dapat lebih mudah memahami isi teks bacaan (Gheytasi et al., 2015)

Memanfaatkan media youtube dalam mempelajari bahasa inggris di Sekolah adalah supaya siswa mampu mencapai tingkat fuctional yaitu berkomunikasi baik secara lisan ataupun tulisan untuk menyelesaikan masalah dalam kehidupan sehari-hari. Ruang lingkup mata pelajaran bahasa inggris di SMP/MTs/sederajat adalah: kemampuan berwacana, kemampuan memahami serta menciptakan berbagai teks fungsional pendek dan monolog serta esai Text dan kompetensi pendukung lainnya yang ada pada silabus.

Pandemi covid-19 telah menghambat berjalannya proses kegiatan belajar mengajar dengan cara konvensional (tatap muka di sekolah). Maka perlu jalan keluar untuk mengatasi hambatan tersebut. Yakni Pembelajaran secara online (daring) adalah salah satu cara untuk mengatasi masalah tersebut. Pembelajaran online (daring) merupakan pembelajaran yang mempergunakan jaringan internet. Pembelajaran daring memacu terjadinya perilaku pembatasan sosial dan mengurangi adanya perkumpulan siswa. Hal ini tentunya dapat menekan potensi penyebaran virus Covid-19 di sekitar sekolah.

Keberadaan media dalam proses pembelajaran Bahasa Inggris memiliki arti yang cukup penting. Mengingat permasalahan selama ini hasil dari pembelajaran Bahasa Inggris dinilai masih kurang. Karena para guru kurang memperhatikan komponen-komponen lain yang dapat membantu proses pembelajaran, di antaranya metode mengajar yang digunakan masih monoton, tanpa menggunakan media yang dapat memberikan gambaran lebih konkrit tentang materi yang disampaikan, sehingga seringkali tujuan dari pembelajaran belum bisa tercapai dengan maksimal. Beberapa penelitian telah menunjukkan bahwa teknologi memberikan banyak pengaruh positif terhadap pembelajaran bahasa seperti membaca, menggunakan video (Gheytasi, Azizifar, \& Gowhary, 2015). Internet telah dipadukan sebagai alat untuk melengkapi aktivitas pembelajaran bahasa (Martins, 2015). Salah satu media teknologi yang sering digunakan saat ini adalah aplikasi di telepon genggam. Hasil penelitian menunjukan bahwa siswa yang banyak berinteraksi dengan aplikasi di telepon genggam dapa lebih muah memahami isi teks bacaan (Gheytasi et al., 2015)

Media pembelajaran adalah alat yang digunakan dalam penyampaian dalam proses pembelajaran (Boovee dalam Simamora, 2009). Pembelajaran merupakan proses komunikasi antara peserta didik,pendidik dan bahan ajar. Komunikasi tidak akan berjalan tanpa bantuan sarana penyampaian pesan atau media.Internet berperan sangat penting dengan generasi saat ini. Mahasiswa sekarang memiliki gaya belajar berbeda dengan generasi sebelumnya. Banyak pihak yang beranggapan bahwa generasi saat ini cepat bosan dan malas belajar. Berbagai penelitian menunjukkan bahwa generasi yang dikenal sebagai generasi internet ini justru memiliki orientasi dan semangat belajar yang tinggi, hanya cara mereka memperoleh informasi saja yang berbeda (Barnes, Marateo, \& Ferris, 2011). Cara belajar generasi ini cenderung independen dan otonom. Akan tetapi mereka adalah para pencari informasi yang gigih dan secara sadar menentukan pilihan model belajar yang sesuai dengan diri mereka. Mereka juga aktif menginginkan model pembelajaran yang variatif dan cenderung cepat bosan dengan model pembelajaran konvensional yang sumber dan modelnya terbatas (Barnes, Marateo, Ferris, 2011).

Berdasarkan hasil interview yang sudah dilaksanakan kepada siswa bahwa kurangnya minat dan semangat belajar siswa yang kurang dikarenakan siswa beranggapan belajar pelajaran bahasa inggris sulit dan rumit, dan kurang menarik serta monotong . masalah ini berpengaruh kepada hasil belajar siswa pada akhir pembelajaran. Apabila kita membahas semangat atau minat belajar siswa, pastinya dapat disebabkan oleh banyak faktor. Contohnya faktor dari dalam diri siswa (instrinsik) maupun faktor dari luar (ekstrinsik). Semangat belajar 
siswa dapat menjadi lebih baik apabila siswa menemukan hal yang menarik pada saat belajar. Begitu juga sebaliknya, semangat belajar siswa akan menurun apabila siswa tidak memperoleh hal yang menarik pada saat proses pembelajaran.

Agar dapat meningkatkan semangat dan minat siswa pada saat belajar bahasa inggris, perlu adanya usaha untuk menemukan cara (metode) serta media pembelajaran yang tepat guna dan menarik untuk dipakai dalam proses kegiatan pembelajaran. Berbagai hasil penelitian, menyimpulkan bahwa suatu media yang digunakan dalam kegiatan belajar mengajar yang tepat mampu meningkatkan semangat siswa dalam belajar yaitu dengan memanfaatkan youtube.

Peneliti memutuskan untuk bekerjasama dengan guru Bahasa Inggris para siswa dan mengadakan penelitian untuk melihat apakah para siswa mampu menunjukkan performa yang lebih baik bila mereka belajar menggunakan media video YouTube. Untuk Beradaptasi dengan era teknologi, kegiatan pembelajaran dituntut mengurangi penggunaan metode ceramah dan dapat diperkaya penggunaan media pembelajaran salah satunya dengan menggunakan media youtube. Lebih- lebih pada kegiatan pembelajaran saat ini yang menekankan pada keterampilan proses dan active learning, maka kiranya peranan media pembelajaran, menjadi semakin penting (Tejo Nurseto, 2012).

Pembahasan mengenai video akan memantik sebuah nama di benak orang-orang sekarang, yaitu YouTube. YouTube merupakan layanan berbagi video (Media, 2009, h. 82) paling dominan dewasa ini (IT WORKS!, 2011, h. 4). CNN Indonesia juga menambahkan bahwa aplikasi YouTube merupakan aplikasi paling popular di Indonesia (Ayuwuragil, 2018). Diperkirakan dari 146 juta pelanggan internet Indonesia tahun 2018, YouTube memiliki sekitar 50 juta pengguna aktif

Media banyak memiliki manfaat untuk digunakan pada saat proses kegiatan belajar mengajar. Ada beberapa pakar menyatakan hal positif (manfaat) dari media pembelajaran. Diantaranya Sudjana dan Rivai (2011:2) menyatakan manfaat media dalam proses belajar siswa yaitu pertama supaya perhatian lebih tertuju pada materi pada saat belajar sehinnga semangat belajar pun semakin meningkat. kedua materi ajar lebih jelas sehingga tujuan dalam kegiatan belajar mengajar mampu tercapai dan siswa mampu menguasai materi dengan baik. Ke tiga siswa banyak melakukan kegiatan pada saat belajar sebab siswa tidak hanya mendengarkan materi yang diberikan guru tetapi siswa memiliki kegiatan lain seperti melakukan pengamatan, mempraktekan sesuatu dan masih banyak yang lainnya. Dari pendapat Sudjana dan Rivai tersebut dapat disimpulkan bahwa manfaat (kegunaan) media dalam pembelajaran yaitu agar dapat memfokuskan kegiatan belajar mengajar menjadi lebih efektif. Sehinnga siswa menjadi lebih bersemangat dan antusias dalam mengikuti proses kegiatan pembelajaran, dan pada akhirnya tujuan pembelajaran awal yang diharapkan bisa tercapai dengan baik.

Asyar (2011:42) dalam bukunya menyatakan: "manfaat dari penggunaan media dalam kegiatan dan proses pembelajaran adalah memperbanyak pemahaman siswa dalam suatu materi, sehingga siswa memiliki banyak pilihan sesuai dengan ciri-ciri ataupun kebutuhan mereka. Bukan hanya materi saja yang menarik, tetapi semangat dan minat belajar siswa juga meningkat sehingga dapat lebih fokus dalam pembelajaran dan efektifitas kegiatan belajar mengajar pun semakin meningkat. Pengertian lain tentang manfaat media pembelajaran dijelaskan oleh Arsyad (2011:26) yang menyatakan bahwa dalam proses belajar mengajar manfaat dari penggunaan media adalah informasi serta pesan dapat disampaikan dengan jelas, perhatian siswa lebih fokus, dan dapat mengatasi keterbatasan ruang dan waktu.

Dari hasil penjelasan tentang kegunaan media dari beberapa pakar di atas, dapat disimpulkan manfaat (kegunaan) media dalam kegiatan pembelajaran antara lain:

1. meningkatkan semangat serta motivasi siswa dalam kegiatan belajar mengajar, sebab dengan digunakannya media pada saat proses kegiatan belajar mengajar berlangsung menjadiakan perhatian dan konsentrasi siswa lebih terfokus pada kegiatan belajar mengajar. 
2. Penyampaian materi lebih luas, tanpa dibatasi oleh tempat dan waktu, hal ini dapat menjadikan siswa lebih aktif pada saat melakukan kegiatan belajar.

Dari pengertian dan penjelasan arti kata "media pembelajaran" dari beberapa pakar, maka dapat disimpulkan bahwa: "media pembelajaran ialah segala sesuatu baik berupa alat atau bahan yang dapat membantu penyampaian suatu pesan atau maksud dalam kegiatan belajar di luar ataupun di dalam kelas sehingga tujuan pembelajaran dapat tercapai secara efektif dan efisien."

Youtube ialah sebuah situs website media yang digunakan untuk membagiakan video secara online. Youtube sangat terkenal dikalangan pengguna internet di seluruh dunia. Youtube dapat digunakan oleh berbagai kalangan dari kalangan usia muda, anak-anak sampai kalangan usia dewasa. Orang yang menggunakan youtube atau lebih dikenal dengan sebutan youtuber dapat mengunggah video, mencari video, melihat video, berdiskusi tentang berbagai hal melalui video atau bagi yang menyukai lagu dapat melihat dan membagikan klip video lagu tanpa harus membayar. Pada setiap hari ada banyak orang dari berbagai negara yang menggunakan youtube. Hal ini dapat dikatakan dengan benar dan pasti bahwa youtube memang sangat populer juga potensial untuk digunakan sebagai media pada saat proses kegiatan belajar. Salah satu penelitian yang dilakukan oleh (Dimyati dan Mujiono: 2006) yang menyatakan bahwa: "melalui video sebagai media pembelajaran membuat kegiatan pembelajaran pada siswa lebih terarah". Selain itu media youtube dinilai dapat memberikan sesuatu hal yang dapat dilihat dan didengar. Dalam proses pembelajaran hal ini mampu memberikan semangat kepada siswa untuk belajar dan juga dapat memberikan pengalaman baru.

Tujuan penggunaan youtube sebagai media pembelajaran yaitu agar dapat menciptakan suasana kegiatan belajar mengajar yang menimbulkan ketertarikan siswa untuk mengukuti proses belajar dari awal sampai akhir, menyenangkan dan juga ada komunikasi dan interaksi yang baik. Video pembelajaran di youtube sangat banyak sehingga guru dapat memilih dan dimanfaatkan untuk kegiatan pembelajaran yang menarik, terutama di masa pandemi ini karena siswa dan guru melaksanakan pembelajaran di rumah. Guru bisa memberikan link youtube kepada siswa untuk dipelajari dan dipahami sesuai dengan materimateri yang ada di kurikulum. Youtube dapat dimanfaatkan sebagai media pembelajaran dan dapat digunakan setiap waktu tanpa batas. Siswa dapat membuka kembali link youtube apabila kurang memahami materinya.

Di masa pandemi covid-19 ini media youtube bisa dimanfaatkan untuk mendapatkan penjelasan, pengertian dan contoh-contoh dalam pembelajaran. Sehingga tercipta suasana pembelajaran yang menarik dan menyenangkan. Penulis memaparkan pemanfaatan youtube pada saat pandemi covid 19 sebagai media pembelajaran dalam upaya meningkatkan vocabulary dan pemahaman siswa dalam pembelajaran bahasa inggris secara mandiri di rumah masing-masing siswa.

\section{METODE PENELITIAN}

Penelitian menggunakan metode kajian pustaka yang menggunakan berbagai referensi seperti buku, jurnal penelitian, dan modul pengelolaan pembelajaran jarak jauh yang diterapkan pada institusi pendidikan atau sekolah. Sumber referensi diperoleh dari karya ilmiah yang terindeks dalam https://scholar.google.co.id, serta bukti (karya ilmiah) serta pengelolaan pembelajaran jarak jauh yang dilakukan oleh universitas terbuka (UT) sebagai rujukan maupun lembaga home schooling yang sudah tepercaya melaksanakan pembelajaran jarak jauh. Kriteria artikel yang digunakan sebagai referensi adalah artikel yang diterbitkan selama 5-10 tahun kebelakang, memiliki ISSN, dan memiliki h-indeks. Pembatasan lingkup kajian dari referensi yang dipilih antara lain penerapan pembelajaran jarak jauh yang efektif, faktor pendukung keberhasilan pelaksanaan pembelajaran jarak jauh, dan sistem pelayanan yang efektif dan efisien dalam pembelajaran jarak jauh.

Penerapan internet sebagai sarana belajar dapat memberikan dampak yang positif 
dalam penggunaan internet dengan peran para pendidik dalam pengelolahannya agar pembelajaran dapat terlaksana dengan efektif (Nugroho, 2012). Pembelajaran yang efektif adalah pembelajaran yang dapat memanfaatkan teknologi informasi dan komunikasi dengan optimal sebagai alat bantu (Hanum, 2013).

Pengumpulan data tidak langsung ditujukan pada sebuah penelitian,tetapi data diambil dari buku, dan juga artikel yang diambil dari Internet. Penulis melakukan identifikasi wacana dari laporan, buku, makalah atau artikel, jurnal, dan informasi lainnya namun melalui dokumen Setelah mengidentifikasi data yang diperoleh, penulis menyimpulkan tentang masalah yang dikaji. Dan dalam hal ini data yang sudah ada kemudian dianalasis. Analisis yang digunakan adalah analisis deskriptif yakni data yang dikumpulkan berupa kata-kata, gambar,,video pembelaran dan bukan angka. Hal ini disebabkan oleh adanya penerapan metode kualitatif. Selain itu, semua data yang dikumpulkan dimungkinkan menjadi kunci terhadap apa yang sudah diteliti. Dengan demikian, peran guru dalam meningkatkan hasil belajara siswa yang efektif dan pengolahan data untuk memberikan gambaran tentang penyajian laporan tersebut Peneliti mengkaji informasi utama yang dibahas dalam referensi , mengaitkan setiap bahasan, dan melakukan pemetaan konsep dalam bentuk tabel perbandingan. Hasil akhir dari penelitian adalah kerangka pelayanan pembelajaran jarak jauh yang komperhensif dan mengembangkan kemandirian belajar siswa serta meningkatkan hasil belajar siswa melalui video youtube.

\section{HASIL DAN PEMBAHASAN}

Penelitian ini menunjukkan bahwa video di Youtube bisa digolongkan menjadi dua jenis. Pertama, video-video yang berupa ceramah atau kuliah bisa digunakan sebagai sumber belajar Bahasa Inggris. Selain itu video-video berbahasa Inggris yang lain seperti video wawancara bisa dipergunakan sebagai sumber data variasi bahasa. Penelitian ini juga menunjukkan bahwa mahasiswa mempunyai persepsi yang positif tentang penggunaan Youtube di kelas Bahasa Inggris.

\section{A. Youtube Sebagai Sumber Belajar}

Ada permasalahan yang tentang proses pembelajaran siswa pada Bab Pendahuluan dalam memaparkan materi ajar pada siswa dengan berbagai topik yang dibahas di kelas Bahasa Inggris di SMP/MTs/sederajat. yakni Topik-topik tersebut seperti Tenses/grammar;reading text; Listening; Speaking dan Writing.. Untuk memperkaya materi, selain dari buku-buku,modul pembelaran yang bersifat manual. video dari Youtube merupakan salah satu media dipergunakan sebagai sumber pembelajaran yang baik dan juga sebagai sumber data. Sehingga guru dapat memilih berbagai jenis video pembelajaran yang ditampilkan selama pelajaran berlangsung yang disesuaikan dengan topik yang dibahas setiap minggunya. Selain itu,ditampilkan juga Video-video lain misalnya adalah uraian materi pelajaran inggris yang relevan dengan bahan ajar di smp/mts pada kelas Inggris sehingga mempermudah siswa dalam mempelajari bahasa inggris. Semua video ini tersedia secara gratis dengan kualitas gambar dan suara yang baik. Pada awal semester siswa mendapatkan silabus lengkap dengan buku referensi wajib dan tambahan. Video dari Youtube yang ditonton di kelas disesuaikan dengan pokok bahasan yang sudah direncanakan setiap pertemuan . siswa ditugaskan membaca buku referensi wajib sebagai buku pegangan siswa dan link.. video Youtube di share ke whatsapp (WA) Mata pelajaran kelas bahasa inggris lalu diputar oleh siswa dan suara diperdengarkan dari speaker ruang . Vidlo di gadget /Hp siswa yang berdurasi pendek atau di bawah 10 menit diputar langsung dan dan terkadang ada Video yang berdurasi panjang itu tegantung lingkup mater ajar .

Dengan menggunakan media youtube , interaksi antara guru dan siswa tidak lagi hanya dilakukan melalui hubungan tatap muka. Guru dapat memberikan layanan tanpa harus berhadapan langsung dengan siswa. Demikian pula siswa dapat memperoleh informasi dalam lingkup yang luas dari berbagai sumber melalui media youtube dengan menggunakan komputer 
atau internet. Hal yang paling mutakhir adalah berkembangnya pembelajaran berbasis media youtube, yaitu proses pengajaran yang dilakukan dengan menggunakan internet. Istilah lain yang makin poluper saat ini ialah e-learning yaitu satu model pembelajaran dengan menggunakan media teknologi komunikasi dan informasi khususnya media youtube. ${ }^{4}$ (Isniatun Munawaroh, 2010).

\section{B. Persepsi siswa tentang Penggunaan Youtube sebagai Sumber Belajar}

Survei untuk mengetahui persepsi siswa dilakukan melalu artikel artikel yang telah dibaca , Jurnal penelitian, dan lain-lain. Berdasarkan referensi penelitian yang ada Ada tiga belas pertanyaan dengan lima pilihan jawaban dengan memakai skala Likert yang meliputi "sangat tidak setuju" sampai dengan "sangat setuju". Selain pertanyaan tertutup dengan pilihan jawaban yang sudah disediakan ada satu pertanyaan terbuka yang memberi tempat mahasiswa untuk menyatakan pendapatan mereka tentang pengintegrasian Youtube di kelas. Bagian pertama meliputi tiga belas pertanyaan yang mencakup sejauh mana persepsi mahasiswa tentang pemakaian Youtube di kelas. Secara umum mahasiswa mempunyai persepsi yang positif tentang pemakaian Youtube di kelas. Dua puluh enam mahasiswa atau $74 \%$ menyatakan setuju dan delapan mahasiswa atau 22,2\% menyatakan sangat setuju bahwa video Youtube meningkatkan minat mereka pada pembelajaran Bahasa Inggris (Seminar Nasional Kedua Pendidikan Berkemajuan dan Menggembirakan (The Second Progressive and Fun Education Seminar) ISBN: 978-602-361-102-7) dengan Tema : Penggunaan Youtube sebagai media pembelajaran aaaaHahasa Inggris Selain itu Seminar Nasional Kedua Pendidikan Berkemajuan dan Menggembirakan Seminar Nasional Kedua Pendidikan Berkemajuan dan Menggembirakan 610 96,3\% mahasiswa menyatakan bahwa pemakaian Youtube menarik. Sebagian besar mahasiswa, yaitu 88,9\% juga menyatakan bahwa video dari Youtube membantu mereka memahami materi dengan lebih baik. Bagian kedua terdiri dari delapan pertanyaan tentang video yang dipakai di kelas. Bagian ini dibagi menjadi dua bagian yaitu pertanyaan yang menyangkut video yang berisi kuliah dari ahli tentang topik tertentu dan pertanyaan tentang video-video yang merupakan contoh atau sumber data dalam pelajaran bahasa inggris. Secara umum persepsi mahasiswa $(88,8 \%)$ adalah positif terhadap video-video yang berisi kuliah tentang topik tertentu. Kebanyakan mahasiswa $(85,2 \%)$ juga mempunyai persepsi yang positif tentang video-video yang dipakai sebagai contoh atau sumber data dalam pelajaran bahasa inggris. Semua mahasiswa mempunyai persepsi yang positif tentang pemakaian Youtube. Ungkapan yang paling banyak muncul adalah kata "menarik". Beberapa mahasiswa mengungkapkan persepsi mereka bahwa video dari internet bisa mengatasi rasa bosan. Selain itu mereka juga menyatakan bahwa pemakaian video dari Youtube telah meningkatkan minat belajar mereka. (Menurut Renda Lestari : Penggunaan Youtube sebagai media pembelajaran bahasa Inggris ; renda_nufrisa@yahoo.com ,Tahun 2017) . Mahasiswa juga menyatakan bahwa penggunaan video dari Youtube lebih menarik daripada hanya membaca sumber belajar dari buku atau mendengarkan uraian materi pelajaran via youtube. Beberapa mahasiswa juga mengungkapkan pentingnya memilih video yang mempunyai kualitas suara dan gambar yang bagus.

Menurut Burke \& Snvder (2008), YouTube merupakan alternatif sumber belajar tepat waktu yang berhubungan dengan video kesehatan bagi pendidik dan peserta didik. Mengintegrasikan video tertentu dari Youtube dapat mengembangkan kemampuan apresiatif mahasiswa dan memberikan pengalaman belajar, tidak hanya terbatas pada materi pelajaran tetapi juga tekhnologi yang digunakan (Sharoff, Leighsa 2011). Dalam program pendidikan keperawatan, youtube dapat digunakan untuk menjelaskan fisiologi tubuh, mempelajari keterampilan klinis dan mendapatkan gambaran visual tentang berbagai gangguan kesehatan yang dialami pasien.

Selain memiliki kelebihan Youtube, terdapat beberapa tantangan atau kekurangan terkait penggunaan YouTube dalam pembelajaran, yaitu: Ketersediaan video hanya tersedia untuk rentang waktu tertentu jadi Tugas pendidik adalah memantau ketersediaan video karena 
beberapa video hanya tersedia untuk rentang waktu tertentu (Burke \& Snvder, 2008) Kualitas Konten. Pendidik harus memperhatikan tanggal video untuk mengetahui bahwa informasi dalam video tidak ketinggalan jaman (Freeman \& Chapman, 2007). kualitas isi karena seringkali video dibuat perorangan tanpa batas. Seringkali video juga melanngar aturan kesusilaan karena menampilkan video yang tidak senonoh (Aqazio \& Bickley, 2008) Sebuah alternatif untuk YouTube, tahun 2007 telah diluncurkan TeacherTube yaitu sebuah komunitas guru online untuk memposting dan melihat video buatan para pendidik. TeacherTube akan lebih mempermudah pencarian video dan menawarkan lebih banyak konten yang tepat bagi mahasiswa Burke \& Snyder (2008) proses pencarian video. Suatu pencarian video bisa menghasilkan tampilan video yang terlalu banyak. Salah satu cara untuk mempersempit pencarian adalah dengan fokus pada username yang meng"upload" video (Trier dalam Sharoff 2011).

Asyar (2011:42) dalam bukunya menyatakan: "manfaat dari penggunaan media dalam kegiatan dan proses pembelajaran adalah memperbanyak pemahaman siswa dalam suatu materi, sehingga siswa memiliki banyak pilihan sesuai dengan ciri-ciri ataupun kebutuhan mereka. Bukan hanya materi saja yang menarik, tetapi semangat dan minat belajar siswa juga meningkat sehingga dapat lebih fokus dalam pembelajaran dan efektifitas kegiatan belajar mengajar pun semakin meningkat. Pengertian lain tentang manfaat media pembelajaran dijelaskan oleh Arsyad (2011:26) yang menyatakan bahwa dalam proses belajar mengajar manfaat dari penggunaan media adalah informasi serta pesan dapat disampaikan dengan jelas, perhatian siswa lebih fokus, dan dapat mengatasi keterbatasan ruang dan waktu.

Beberapa kelebihan menggunakan Youtube Live sebagai media kuliah online adalah sebagai berikut:

Bisa share screen(membagikan layar), sehingga saya bisa menjelaskan dengan Power Point atau menampilkan wajah saya. Bisa juga mendemonstrasikan langkah-langkah analisis data dengan software (kebetulan saya mengajar Statistika). Bisa interaktif dengan mahasiswa melalui live chat. Mahasiswa dapat berdiskusi dan bertanya melalui live chat, sehingga interaksi dosen-mahasiswa tetap terjaga. Mahasiswa juga umumnya lebih aktif jika menyampaikan pertanyaan melalui chat dibandingkan secara langsung.

1. Lebih hemat kuota data. Youtube dari sisi peserta tentu lebih memakan kuota yang lebih kecil jika dibandingkan kita menggunakan Zoom atau Google Meet. Selain itu, bagi pengguna Telkomsel, mereka juga bisa beli paket data ngeteng khusus Youtube (hanya 3 ribu Rupiah) (ini bukan endorse, saya ga dibayar Telkomsel, hanya ngasih tahu). Anggap saja ini uang bensin kalau mereka harus ke kelas.

2. Video perkuliahan bisa tetap terdokumentasi di Channel Youtube, termasuk live chatnya. Hal ini cukup membantu mahasiswa yang lambat belajar, sehingga mereka dapat mengulang-ulang materi berapa kalipun mereka mau. Begitu juga jika mahasiswa berhalangan hadir secara real timesaat jam kuliah, mereka tetap bisa mendapatkan materi kuliah melalui Channel Youtube.

3. Bisa dilaksanakan secara klasikal dalam jumlah besar. Saya sendiri menggabungkan tiga kelas menjadi satu sesi. Dengan demikian saya juga lebih efisien, tidak perlu menyampaikan materi yang sama berulang-ulang di kelas yang berbeda.

4. Karena perkuliahan hampir sama dengan model ceramah di kelas, jadi mahasiswa tidak terlalu terbebani dengan tugas, dosen juga tidak terbebani dengan koreksian.

Meskipun demikian tetap ada keterbatasan Youtube Live ini, misalnya:

1. Tidak cocok untuk metode belajar model diskusi. Hal ini karena Youtube hanya memungkinkan satu orang sebagai pembicara, sedangkan yang lain hanya bisa menanggapi melalui live chat.

2. Koneksi internet pengajar harus stabil. Hal ini penting karena lancar atau tidaknya perkuliahan sangat tergantung dari koneksi internet pengajar. Selain itu kuota data yang digunakan juga lebih besar karena mereka sama saja mengupload video dengan durasi waktu yang cukup lama. Saya biasa menghabiskan lebih dari 2GB untuk sekali kuliah. 
3. Pengajar harus familiar dengan pengoperasian alat streaming Youtube. Nyatanya melakukan live streaming Youtube tidak sesederhana melakukan share screen dengan Zoom atau Google Meet, jadi perlu uji coba dulu.

Untuk live di Youtube sendiri ada dua metode, pertama live dengan Webcam dan kedua live streaming. Live dengan Webcam prosesnya lebih mudah, sama seperti live di Instagram, namun kita hanya bisa menampilkan wajah kita saja dan ini tentu saja tidak terlalu membantu untuk perkuliahan. Sedangkan untuk metode live streaming kita dapat membagikan apapun yang ada di komputer kita, mulai dari power point, kamera, dokumen, dan apapun yang kita buka di komputer kita. Metode live streaming ini tidak bisa dilakukan otomatis melalui Youtube, namun kita butuh program pihak ketiga yang menjadi perantara (encoder) antara Windows kita dengan Youtube. Untuk encoder saya menggunakan yang gratisan yakni OBS (Open Broadcaster Software).Untuk memastikan bagaimana bahwa mahasiswa memang menyimak materi yang disampaikan di Youtube?

Ada beberapa cara yang dapat digunakan sebagai parameter keberhasilan pembelajaran kita.

1. Youtube telah menyediakan Analytics terhadap proses live streaming yang dilakukan. Berapa jumlah orang yang terlibat dan berapa menit rata-rata orang mengikuti live streaming. Meskipun parameter ini secara keseluruhan dan tidak menunjukkan individu, namun ini bisa menjadi gambaran awal apakah mahasiswa kita mengikuti kuliah secara penuh atau tidak.

2. Melalukan absensi dan asesmen pemahaman terhadap materi yang dijelaskan. Cara dan waktu untuk absen hanya dijelaskan pada waktu tertentu di video. Misal pada materi analisis korelasi dengan SPSS, di akhir materi saya memberi tahu link untuk mereka bisa presensi. Presensi dilakukan di Google form disertai satu pertanyaan mengenai analisis korelasi. Jadi agar mereka bisa tahu link absen, mereka harus menyimak video kuliah, dan agar mereka bisa menjawab satu pertanyaan di absen itu, mereka harus benar-benar memahami materinya.

3. Meskipun saya tidak mewajibkan siswa untuk bisa mengikuti pelajaran real time, tapi link untuk mengisi absen dan menjawab soal dibuat hanya aktif 24 jam. Hal ini perlu dilakukan agar mahasiswa terpacu bekerja tepat waktu.

\section{SIMPULAN}

Berdasarkan pemaparan di atas, maka dapat disimpukan bahwa pembelajaran bahasa inggris yang menggunakan media you tube sangat mengasyikan karena banyak fasilitas yang bisa kita temukan di youtube bervariasi sehingga siswa bisa memilih sesuai dengan keinginan mereka masing-masing. Materi- materi ajar pelajaran bahasa inggris juga banyak didapatkan dan dapat diakses dengan mudah dan cepat. Youtube mampu meningkatkan minat dan motivasi siswa serta dapat meningkatkan pembelajaran bahasa inggris melalui youtube Hal ini pun dapat dilihat dari antusias siswa pada saat mengirimkan tugas pada akhir pembelajaran yaitu berupa pembuatan Tugas Siswa Cards tersebut lalu dibagikan digrup mata pelajaran khusus pelajaran bahasa inggris. Sehingga bisa dipantau oleh guru dan juga siswa lain dapat melihatnya.

Dampak penggunaan media YouTube terhadap siswa teridi dari beberapa kelebihan serta kekurangan, adapun kelebihan youtube yakni 1) efektif karena dapat diakses secara gratis, 2) Informatif ,dapat memberikan informasi terhadap pekembangan ilmu dan teknologi, 3) bersifat universal, 4) Reviewable , karena dapat dipatau secara berulang-ulang. 5) Mengembangkan imaginasi dan meningkatkan kreatifitas peserta didik ,6) Praktis , dapat dimanfaatkan dengan muda pada semua kalangan, serta 6) intraktif , dapat memfasilitas untuk diskusi dan tanya jawab .sedangkamn kekurangan youtube sebagai media pembelajaran yaitu 1) Jaringan internet terkadang lambat sehingga memutar ideo pembelajaran kurang maksimal, 2) resolusi gambar yang kurang jelas jika diunduh dengan kapasitas rendah, 3) Apabila tidak ada internet, pengajar harus mengunduh (download) video pembelajarannya sebelum 
mengajar , 4) Dapat disalahgunakan oleh penggunanya pada hal-hal yang tidak berguna, 5) Karena terlalu bebas upload jadi banyak video yang tidak berguna atau video pornografi yang ikut terupload, 6) banyak informasi yang menyesatkan dengan mudah dapat mempengaruhi peserta didik

\section{DAFTAR PUSTAKA}

Azhar Arsyad. (2011). Media Pembelajaran. Jakarta: Raja Grafindo Persada.

Ayuwuragil, K. (2018). Youtube Jadi Aplikasi Media Paling Populer di Indonesia. CNN

Indonesia. https://www.cnnindonesia.com/teknologi/20180406202852 n213288967/youtubejadi-aplikasi-media-paling-populer-di-indonesia.23 November 2020. 19:47.

Barnes, K., R. Marateo, and S. Ferris. (2007). Teaching and learning with the net generation. Innovate, 3 (4).

Bashir, A. (2020). Menulis Best Practice. Pelatihan Jarak Jauh Online Menulis Jurnal. rumah belajar matematika indonesia.

Burke, S.C., Snyder, S., Rager, R.C. (2009). An Assessment of Faculty Usage of Youtube as a Teaching Resource. The Internet Journal of Allied Health Sciences and Practice. Vol. 7 No. 1 ,

Dimyati dan Mujiono. (2006). Belajar dan Pembelajaran. Jakarta: Rineka Cipta

Duffy, P. "Engaging the Youtube Google-Eyed Generation: Strategies for Using Web 2.0 in Teaching and Learning." The Electronic Journal of e-Learning Volume 6 Issue 2, pp 119 - 130, available online at www.ejel.org

Hanum, N. S. (2013). Keefetifan e-learning sebagai media pembelajaran (studi evaluasi model pembelajaran e-learning SMK Telkom Sandhy Putra Purwokerto). Jurnal Pendidika Vokasi, 3(1), 90-102. https://doi.org/10.21831/jpv.v3i1.1584

Hartoyo. (2010). Teknologi Informas dan Komumikasi. Semarang: Pelita Insani

Kemdikbud. (2016). Peraturan Menteri Pendidikan dan Kebudayaan nomor 22 tahun 2016 tentang Standar Proses Pendidikan Dasar dan Menengah. Jakarta: Kemdikbud.

Media, L. 2009. YouTube dan Google Video: Membuat, Mengedit, dan Upload Video. Mediakom. ISBN: 979-0813910

Munawaroh, Isniatun. (2010). "Pemanfaatan Teknologi Informasi dan Komunikasi Untuk Menumbuhkan Kreativitas dan Kemandirian Belajar."Universitas Negeri Yogyakarta

Nugroho, A. (2012). Pengembangan Model Pembelajaran. Jurnal Transformatika, 9(2) : 2944.

Pembelajaran Daring diambil dari : https://doi.org/10.22437/bio.v6i2.9759

Simamora, L. (2003). Cakrawala Pendidikan E-Learning: Konsep dan Perkembangan Teknologi yang Mendukung. Jakarta: UT.

Kata youtube sering kita dengar. Youtube ialah sebuah situs website media yang digunakan untuk membagiakan video secara online. Youtube sangat terkenal dikalangan 